Article

\title{
An Investigation on the Synthesis of Molybdenum Oxide and Its Silica Nanoparticle Composites for Dye Degradation
}

\author{
Olfa Kamoun $^{1}{ }^{\circledR}$, Abdelaziz Gassoumi ${ }^{2, *}$, Salah Kouass ${ }^{3}{ }^{\circledR}$, Badriyah Alhalaili ${ }^{4}$, \\ Ruxandra Vidu ${ }^{5,6, *(D)}$ and Najoua Turki-Kamoun ${ }^{1}$ \\ 1 Laboratoire de Physique de la Matière Condensée, Faculté des Sciences de Tunis, \\ Université de Tunis El Manar, Tunis 2092, Tunisia; o.kamoun@yahoo.fr (O.K.); \\ n.najouakamoun@gmail.com (N.T.-K.) \\ 2 Department of Physics, Faculty of Science, King Khalid University, P.O. Box 9004, Abha 61413, Saudi Arabia \\ 3 Laboratoire Matériaux Utiles, Institut National de Recherche et d'Analyse Physico-Chimique (INRAP) \\ Sidi Thabet, Ariana 2020, Tunisia; kouasssa@gmail.com \\ 4 Nanotechnology and Advanced Materials Program, Kuwait Institute for Scientific Research, P.O. Box 24885, \\ Safat 13109, Kuwait; bhalaili@kisr.edu.kw \\ 5 Department of Electrical and Computer Engineering, University of California Davis, Davis, CA 95616, USA \\ 6 Faculty of Materials Science and Engineering, University POLITEHNICA of Bucharest, \\ 313 Splaiul Independentei, RO-060042 Bucharest, Romania \\ * Correspondence: abdelaziz.gassoumi@gmail.com (A.G.); rvidu@ucdavis.edu (R.V.)
}

Received: 6 November 2020; Accepted: 29 November 2020; Published: 2 December 2020

\begin{abstract}
The molybdenum oxide $\left(\mathrm{MoO}_{3}\right)$ and $\mathrm{MoO}_{3} @ \mathrm{SiO}_{2}$ nanoparticles were successfully prepared using the chemical bath deposition (CBD) method. The photocatalytic activities of molybdenum oxide $\left(\mathrm{MoO}_{3}\right), \mathrm{SiO}_{2}$, and $\mathrm{MoO}_{3} @ \mathrm{SiO}_{2}$ nanoparticles composite have shown a synergistic photocatalytic effect of $\mathrm{SiO}_{2}$ combined with $\mathrm{MoO}_{3}$. The first-order degradation rate constants for $\mathrm{MoO}_{3}, \mathrm{SiO}_{2}$, and $\mathrm{MoO}_{3} @ \mathrm{SiO}_{2}$ nanocomposite were $10.3 \times 10^{-3} \mathrm{~min}^{-1}, 15.1 \times 10^{-3} \mathrm{~min}^{-1}$, and $16.3 \times 10^{-3} \mathrm{~min}^{-1}$, respectively. The $\mathrm{MoO}_{3} @ \mathrm{SiO}_{2}$ composite showed degradation efficiencies in the methylene blue solution close to $100 \%$ after $60 \mathrm{~min}$ of UV irradiation. The X-ray diffraction (XRD) showed that the $\mathrm{MoO}_{3}$ powder has a hexagonal crystal structure and the silica is the tridymite type of $\mathrm{SiO}_{2}$. The crystallite size was about $94 \mathrm{~nm}, 32 \mathrm{~nm}$, and $125 \mathrm{~nm}$ for $\mathrm{MoO}_{3}$, silica, and $\mathrm{MoO}_{3} @ \mathrm{SiO}_{2}$, respectively, as calculated by the Scherrer equation. The scanning electron microscopy (SEM) images revealed that the $\mathrm{MoO}_{3}$ powder consisted of a uniform hexagonal structure; the silica showed a rod-like micro-flake morphology and the $\mathrm{MoO}_{3} @ \mathrm{SiO}_{2}$ composite had the appearance of coral-like structures.
\end{abstract}

Keywords: $\mathrm{MoO}_{3}$ nanoparticles; silica; nanoparticle composite; structural properties; photocatalytic properties; methylene blue

\section{Introduction}

Catalytic materials were developed over the years to purify the polluted water and air, where the heterogeneous photocatalysis plays an important role [1-5]. The well-known transition metal oxide photocatalysts are $\mathrm{ZnO}$ [6], $\mathrm{TiO}_{2}$ [7], $\mathrm{WO}_{3}$ [8], and $\mathrm{MoO}_{3}$ [9]. The oxidation process of heterogeneous photocatalysis is achieved by using light to activate the catalyst and to generate highly reactive free radicals, which then reduce particular organic compounds [6,7,9-11]. When the mineralization process is finished, the outcome consists of $\mathrm{H}_{2} \mathrm{O}$ and $\mathrm{CO}_{2}$.

The photocatalytic mechanism is activated when the oxide semiconductor is immersed in a liquid or placed in a gaseous medium and then irradiated with light of an energy that is equal to or greater 
than its bandgap [11]. In this case, electron-hole pairs are generated on the surface of the semiconductor and subsequent chemical reactions with the environmental media lead to the production of free radicals, which degrade the organic pollutants $[10,11]$.

Photocatalysis requires a large surface area for reaction. The exterior of natural silica is covered with a network of pores to optimize the capture of light. This feature of silica has attracted the attention of nanotechnologists. Moreover, silica is a phylum of unicellular microalgae (from $2 \mu \mathrm{m}$ to $1 \mathrm{~mm}$ ) present in all aquatic environments, and the majorities are in biofilms (with a preference for cold water) and enveloped by a siliceous external skeleton. The degradation of MB under the visible light has been demonstrated for photocatalysts prepared using green and renewable resources [12]. Mesoporous silica impregnated with Pt-Porphyrin or PtNPs [13] and titania sensitized with porphyrin [14] or magnetic photocatalyst porphyrin [15] has also been shown visible-light-driven photocatalysis. $\mathrm{MoO}_{3}$ is one of the most promising metal oxides because of its many advantages, such as its non-toxic nature, and can be widely used in an organic light-emitting diode, gas sensing, catalysis, transistors, and solar cells [16-18]. The smaller the particle size of $\mathrm{MoO}_{3}$, the larger the surface area, which potentially increases the adsorption methylene blue and photoactive sites, resulting in enhanced photocatalytic activity $[9,16,19]$. Various methods have been used to optimize the preparation and processing technology of molybdenum oxide films, such as thermal evaporation, sol-gel deposition, and chemical vapor deposition [20-22]. In our work, we used a simple and inexpensive chemical bath deposition (CBD) technique because the film properties can be optimized through various deposition process parameters. The CBD technique has received great consideration from the research community for the production of low-cost semiconductor photocatalyst.

In our search for novel and sustainable photocatalysts, we used the unique architecture of silica and high surface area to increase the degradation efficiency of the organic dyes. Because $\mathrm{MoO}_{3}$ has shown good photocatalytic degradation properties [23-25], present in this study the synthesis of a novel $\mathrm{MoO}_{3}$ and $\mathrm{SiO}_{2}$ nanoparticle composites, labeled $\mathrm{MoO}_{3} @ \mathrm{SiO}_{2}$, and their photocatalytic properties. The main objective of this work is to study the photocatalytic activities of the films for the photodegradation of methylene blue (MB) under UV light, as well as examine the physical properties of the $\mathrm{MoO}_{3}$ films.

\section{Experimental and Characterization Details}

The chemical bath deposition (CBD) method was performed to synthesize nanocrystalline $\mathrm{MoO}_{3}$ and $\mathrm{MoO}_{3}$ on $\mathrm{SiO}_{2}$, as illustrated in Figure 1. In a typical synthesis, an aqueous solution of $15 \mathrm{~mL}$ of $0.05 \mathrm{M}\left(\mathrm{NH}_{4}\right)_{6} \mathrm{Mo}_{7} \mathrm{O}_{24} \cdot 4 \mathrm{H}_{2} \mathrm{O}\left(99 \%\right.$, Merck, Kenilworth, NJ, USA) solution was mixed with $\mathrm{SiO}_{2}$ in a reaction bath. The temperature of the reaction bath was slowly increased to $50{ }^{\circ} \mathrm{C}$. Then, $5 \mathrm{~mL}$ of concentrated $\mathrm{HNO}_{3}$ (ACS reagent, $\geq 90.0 \%$ ) was added dropwise with constant stirring until the $\mathrm{pH}$ of the solution was 2.2, and a clear solution was obtained. Then, after the solution was stirred for $15 \mathrm{~min}$, the temperature of the reaction bath was raised to $70{ }^{\circ} \mathrm{C}$, where the initial seeds started to form. The reaction bath was held at $70{ }^{\circ} \mathrm{C}$ for $30 \mathrm{~min}$, during which time a white precipitate of h-MoO nanoparticles was observed. When the synthesis was complete, the white precipitate was filtered using deionized water and then dried in an oven at a constant temperature of $110^{\circ} \mathrm{C}$ for $1 \mathrm{~h}[26,27]$.

The nanoparticle composites were analyzed by X-ray diffraction (XRD) scanning electron microscopy (SEM), and UV-Vis spectroscopy. The XRD patterns were recorded on an X'pert PRO X-ray diffractometer (Malvern Panalytical Ltd, Malvern, UK) with graphite monochromatized Cu K $\alpha$ radiation source (1.5406 ̊). Morphologies of nanopowders were examined using a JEOL-JSM-6490 LV scanning electron microscope (SEMTech Solutions, Inc., North Billerica, MA, USA) and absorbance measurements were performed using a Perkin Elmer Lambda 950 spectrometer (Perkin Elmer, Waltham, MA, USA). The UV irradiation was performed at $254 \mathrm{~nm}$ wavelength using an $8 \mathrm{~W}$ power lamp (Philips Germicidal Ultraviolet-C, Philips Lightning, Eindhoven, The Netherlands). 


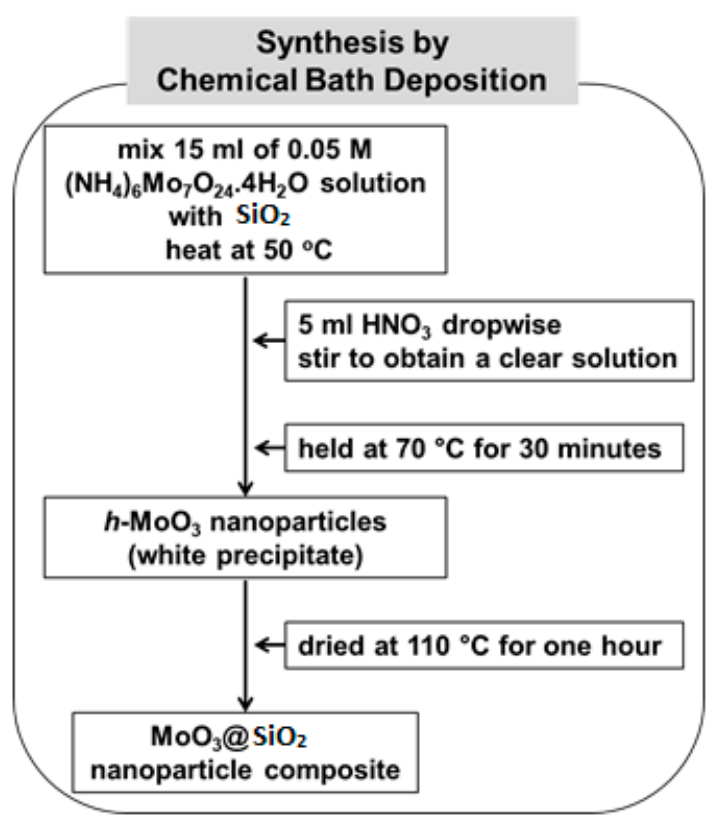

Figure 1. Illustration of the processing steps in the synthesis of $\mathrm{MoO}_{3} @ \mathrm{SiO}_{2}$ nanoparticle composites.

\section{Results and Discussion}

\subsection{Structural Properties}

Both $\mathrm{MoO}_{3}$ nanoparticles and $\mathrm{SiO}_{2}$ were analyzed by X-ray diffraction analysis and compared to the $\mathrm{MoO}_{3} @ \mathrm{SiO}_{2}$ nanoparticles composite. Figure 2 shows the XRD patterns of the $\mathrm{MoO}_{3}, \mathrm{SiO}_{2}$, and $\mathrm{MoO}_{3} @ \mathrm{SiO}_{2}$ nanoparticles grown by chemical bath deposition. The diffraction patterns correspond to the $\mathrm{h}-\mathrm{MoO}_{3}$ phase for the $\mathrm{MoO}_{3}$ nanoparticles and to tridymite, which is the monoclinic phase corresponding to $\mathrm{SiO}_{2}$ for the silica [28].

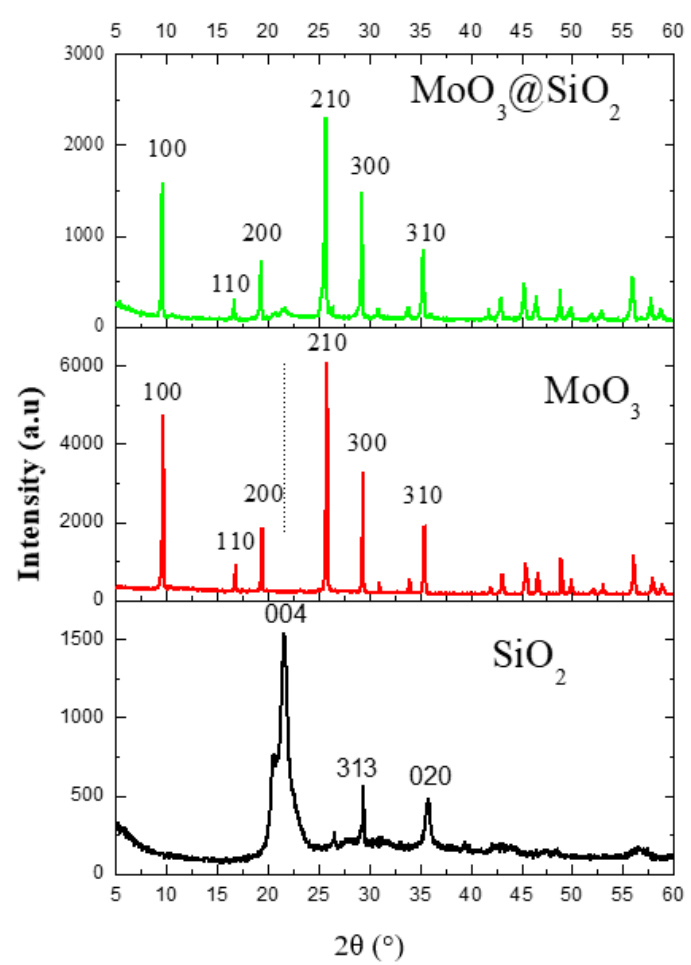

Figure 2. The XRD patterns for the $\mathrm{SiO}_{2}, \mathrm{MoO}_{3}$, and the $\mathrm{MoO}_{3} @ \mathrm{SiO}_{2}$ composite. 
Tridymite is a species of mineral of the tectosilicate family, and one of the polymorphs of silica with quartz, coesite, cristobalite, stishovite, having the chemical formula of $\mathrm{SiO}_{2}$ and containing traces of titanium, aluminum, iron, manganese, magnesium, calcium, sodium, and potassium.

$\mathrm{MoO}_{3}$ has the following lattice parameters: $\mathrm{a}=10.53 \AA$ and $\mathrm{c}=14.876 \AA$ (JCPDS card no. 21-0569) [19]. The $\mathrm{SiO}_{2}$ has the following lattice parameters: $a=25.93 \AA, b=5.01 \AA$, and $c=18.54 \AA$, with the highest intensity at $2 \theta=21.6^{\circ}$, matching the reference R090042 [29].

The crystallite size can be estimated from the full width half maximum (FWHM) values obtained from the predominant (210) for $\mathrm{MoO}_{3}$ and $\mathrm{MoO}_{3} @ \mathrm{SiO}_{2}$ diffraction peak at $2 \theta=25.7^{\circ}$ according to the following Debye-Sherrer equation [30-32]:

$$
\mathrm{D}=0.9 \lambda / \beta \cos \theta
$$

where $\lambda$ is the wavelength of $\mathrm{Cu}-\mathrm{K} \alpha 1$ radiation $(1.5406 \AA)$ and $\theta$ is the Bragg diffraction angle. The crystallite sizes calculated with Equation (1) were around 94, 32, and $125 \mathrm{~nm}$ for $\mathrm{MoO}_{3}$, $\mathrm{SiO}_{2}$, and $\mathrm{MoO}_{3} @ \mathrm{SiO}_{2}$, respectively. The observed broadening of the $\mathrm{SiO}_{2}$ peak(004) in the $\mathrm{MoO}_{3} @ \mathrm{SiO}_{2}$ spectrum is attributed to the size and strain effect between $\mathrm{MoO}_{3}$ and $\mathrm{SiO}_{2}$ [19].

In the XRD spectra of the $\mathrm{MoO}_{3} @ \mathrm{SiO}_{2}$ composite, all peaks attributed to the $\mathrm{MoO}_{3}$ phase are observed, which confirms that the $\mathrm{MoO}_{3}$ nanoparticles are well grown on the $\mathrm{SiO}_{2}$ surface. It was also observed that the intensity for all $\mathrm{MoO}_{3}$ peaks decreases for $\mathrm{MoO}_{3} @ \mathrm{SiO}_{2}$ composite compared to those of $\mathrm{MoO}_{3}$. Note the existence of the preferential $\mathrm{SiO}_{2}$ peak at $2 \theta=21.6^{\circ} . \mathrm{All} \mathrm{MoO}_{3} @ \mathrm{SiO}_{2}$ peaks decreased in intensity, which may be due to the fact that $\mathrm{MoO}_{3}$ nanoparticles are well-formed on the surface of $\mathrm{SiO}_{2}$, but in a dispersed manner.

\subsection{Morphological Analysis}

Surface morphology of the nanoparticles composite and constituent nanoparticles were investigated by using SEM analyses. The nanoparticles of $\mathrm{MoO}_{3}$ consist of a uniform hexagonal rod-like morphology. The regular faceted surface of each hexagonal rod [33] is clearly seen in Figure 3a. In Figure 3b, stems have developed out of a central point [34], with flower-like clusters of hexagonal $\mathrm{MoO}_{3}$ stem-shaped petals. The SEM images of $\mathrm{SiO}_{2}$ (Figure 3c) shows a similar morphology as $\mathrm{SiO}_{2}$ [35]. The morphology of $\mathrm{SiO}_{2}$ depicts mostly micro-flake and irregular rod-shaped with particles agglomeration. Regarding the $\mathrm{MoO}_{3} @ \mathrm{SiO}_{2}$ composite (Figure 3d,e), we observed the appearance of coral-like structures in the form of hexagonal rods. The morphology of this composite indicates the incorporation of $\mathrm{MoO}_{3}$ into the $\mathrm{SiO}_{2}$ in the $\mathrm{MoO}_{3} @ \mathrm{SiO}_{2}$ composite, which is in agreement with the XRD analysis in Figure 2. SEM observation shows that the specific surface area increased for the $\mathrm{MoO}_{3} @ \mathrm{SiO}_{2}$ composite compared to those for $\mathrm{MoO}_{3}$ or $\mathrm{SiO}_{2}$. Increasing the specific surface area, especially in the case of $\mathrm{MoO}_{3} @ \mathrm{SiO}_{2}$, could play an important role in improving sensitivity in optoelectronic applications like photocatalysis and gas sensors. 


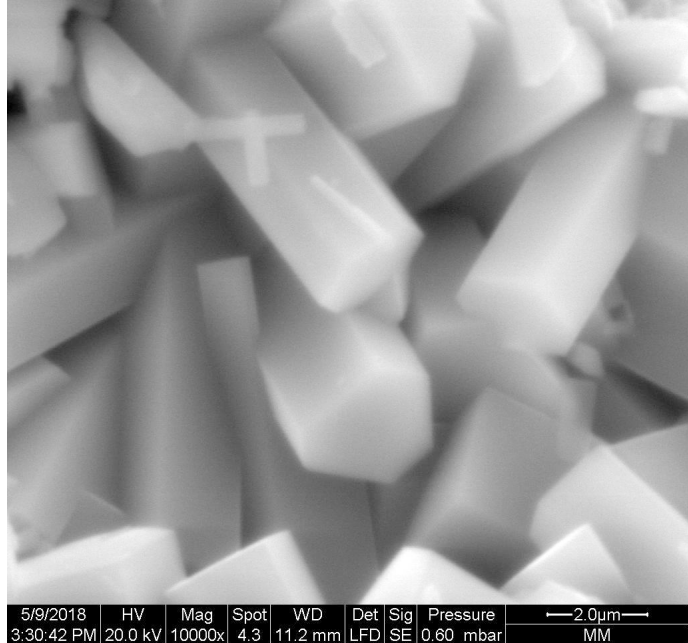

(a) $\mathrm{MoO}_{3}$

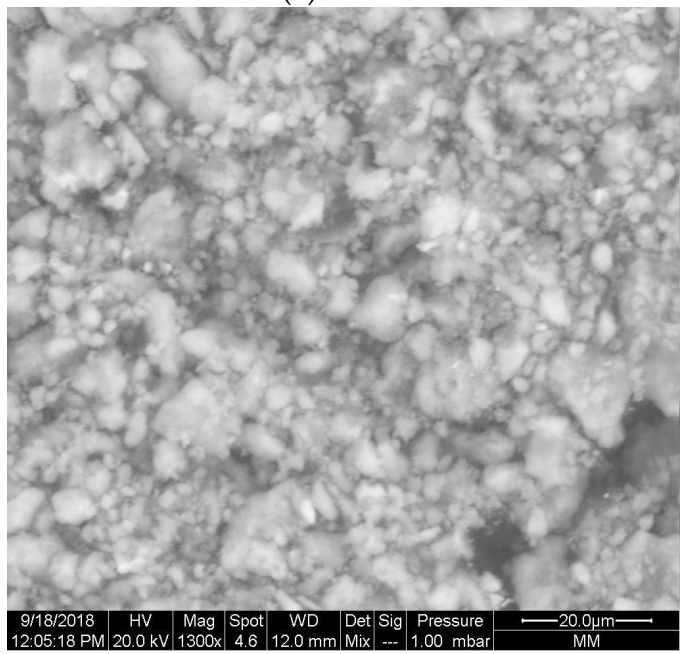

(c) $\mathrm{SiO}_{2}$

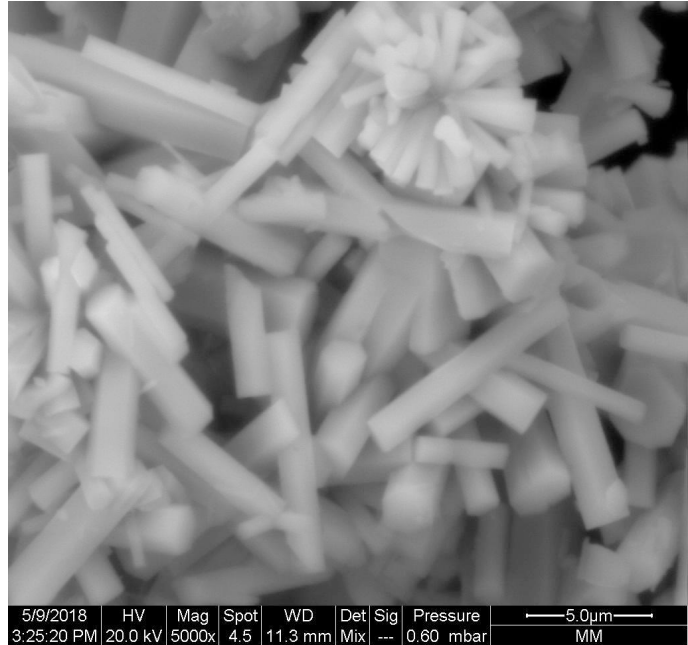

(b) $\mathrm{MoO}_{3}$

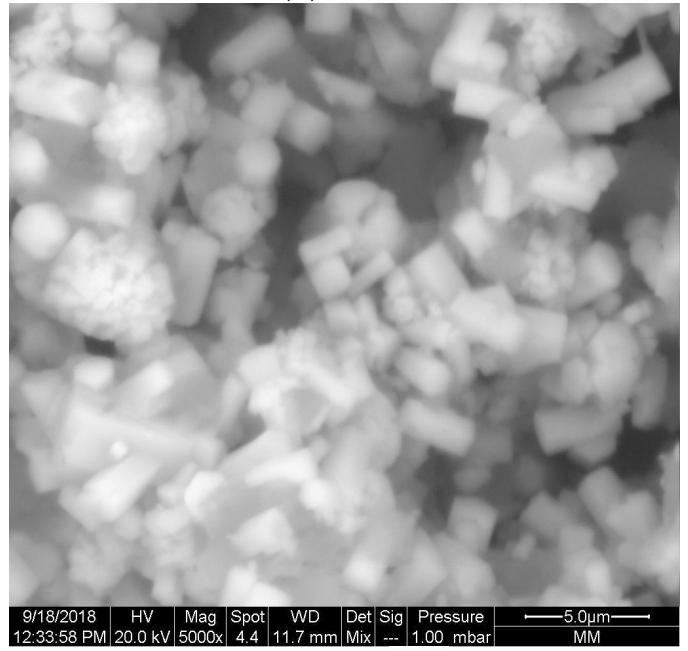

(d) $\mathrm{MoO}_{3} @ \mathrm{SiO}_{2}$

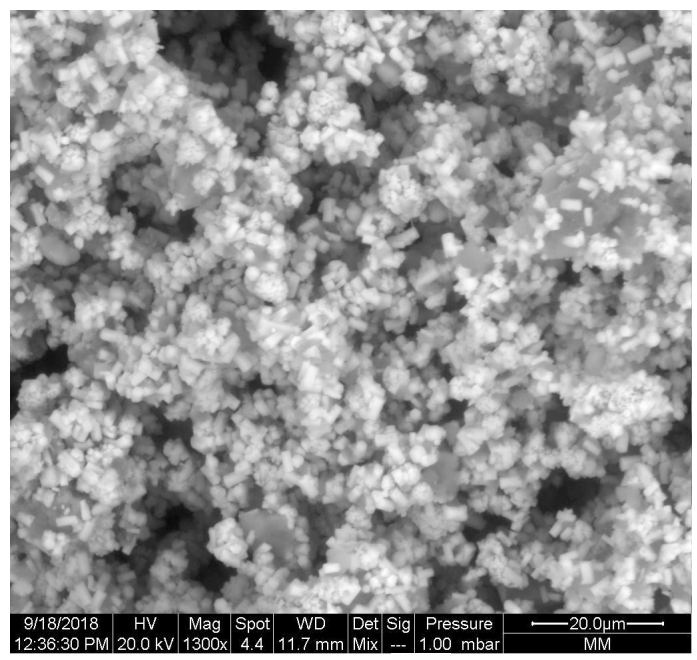

(e) $\mathrm{MoO}_{3} @ \mathrm{SiO}_{2}$

Figure 3. SEM micrographs of $\mathrm{MoO}_{3}$ nanoparticles (a,b), silica particles (c), and $\mathrm{MoO}_{3} @ \mathrm{SiO}_{2}$ nanoparticles composites $(\mathbf{d}, \mathbf{e})$ at different magnifications. 


\subsection{Photocatalytic Studies}

$\mathrm{MoO}_{3}$ nanoparticles were used as photocatalyst for the degradation of methylene blue (MB), which was used as a model compound. It was found that there was no MB degradation in the dark and in the presence of $\mathrm{MoO}_{3}, \mathrm{SiO}_{2}$, and $\mathrm{MoO}_{3} @ \mathrm{SiO}_{2}$. In this work, we have monitored the $\mathrm{MB}$ degradation under UV light at different times with $\mathrm{MoO}_{3}, \mathrm{SiO}_{2}$, and $\mathrm{MoO}_{3} @ \mathrm{SiO}_{2}$ nanoparticle catalysts. Figure 4 presents the UV-Vis absorption spectra of $\mathrm{MoO}_{3}$ nanoparticles, $\mathrm{SiO}_{2}$ and $\mathrm{MoO}_{3} @ \mathrm{SiO}_{2}$ nanoparticles exposed to UV light for different times.

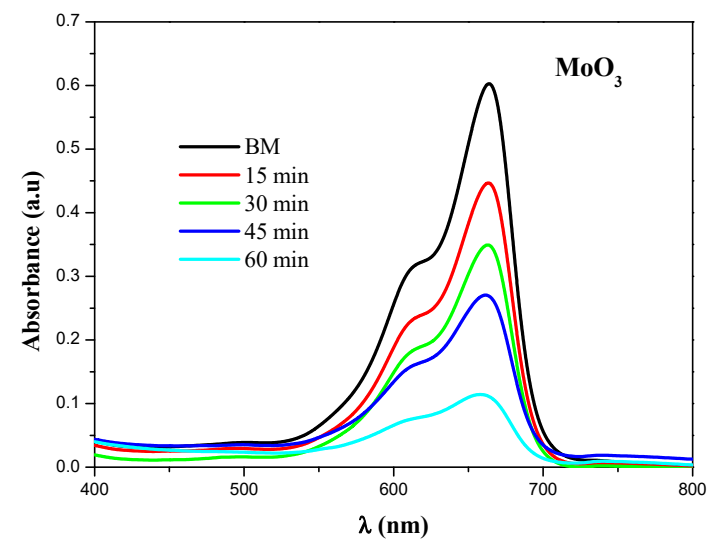

(a)

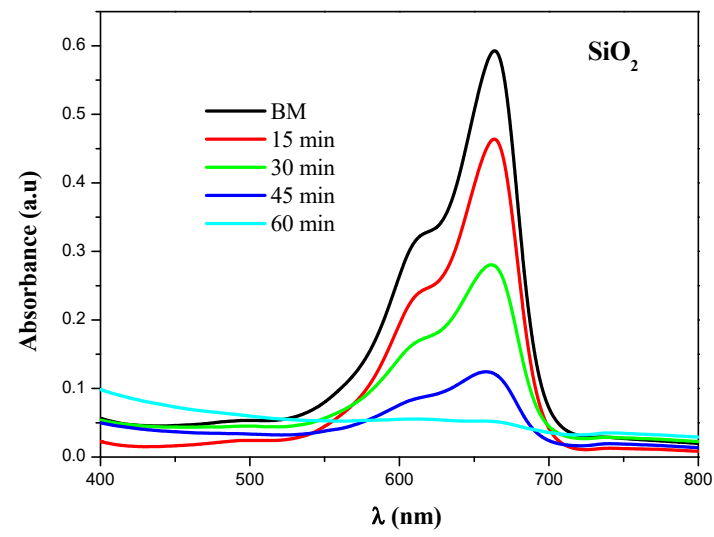

(b)

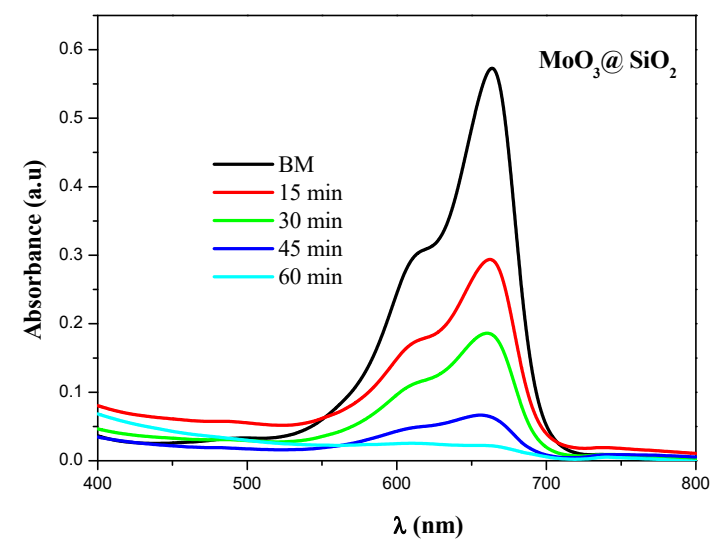

(c)

Figure 4. UV-Vis absorption spectra of $\mathrm{MoO}_{3}$ nanoparticles (a), $\mathrm{SiO}_{2}(\mathbf{b})$ and $\mathrm{MoO}_{3} @ \mathrm{SiO}_{2}$ (c).

There are two different absorption bands for the aqueous cationic MB dye solution, i.e., at $293 \mathrm{~nm}$ $(\pi-\pi *)$ and $664 \mathrm{~nm}\left(n-\pi^{*}\right)$ [34]. In this work, the intensities of the absorption peaks at $664 \mathrm{~nm}$ decrease 
with increasing the time of irradiation, compared to the catalyst-free solution. The degradation of the MB solution containing $\mathrm{h}-\mathrm{MoO}_{3}$ catalyst synthesized by CBD was $90 \%$ [34].

During photocatalysis, the electrons in the valence band of the oxide semiconductor are excited under UV light radiation and leave holes in the valence band after they jump to the conduction band. The holes combine with $\mathrm{H}_{2} \mathrm{O}$ to produce $\cdot \mathrm{H}$ and $\cdot \mathrm{OH}$ radicals. In the meanwhile, the electrons in the conduction band scattered towards the adsorbed $\mathrm{O}_{2}$ to generate activated $\cdot \mathrm{O}_{2}$ [36] with the consequent transformation of the water molecules into $\cdot \mathrm{OH}$ radicals.

The mechanism of photocatalytic degradation for $\mathrm{MoO}_{3}$ nanoparticles is similar to that of a metal oxide semiconductor [37], as follows:

$$
\begin{gathered}
\mathrm{MoO}_{3} \text { (or } \mathrm{SiO}_{2} \text { or composite) }+\mathrm{h} v \rightarrow \mathrm{MoO}_{3}\left(\mathrm{e}^{-}+\mathrm{h}^{+}\right. \text {) } \\
\mathrm{h}^{+}+\mathrm{OH}^{-} \rightarrow \mathrm{OH} \text { (hydroxide) } \\
\mathrm{e}^{-}+\mathrm{O}_{2} \rightarrow \mathrm{O}_{2}^{-} \text {(super oxide anion) } \\
\mathrm{OH}+\mathrm{MB}^{-} \rightarrow \mathrm{MB}^{*} \text { (intermediate) } \rightarrow \mathrm{CO}_{2}+\mathrm{H}_{2} \mathrm{O} \\
\mathrm{O}_{2}{ }^{-}+\mathrm{MB} \rightarrow \mathrm{MB}^{*} \text { (intermediate) } \rightarrow \mathrm{CO}_{2}+\mathrm{H}_{2} \mathrm{O}
\end{gathered}
$$

These oxidizing species can degrade the $\mathrm{MB}$ dye into chemical forms of $\mathrm{CO}_{2}$ and $\mathrm{H}_{2} \mathrm{O}$, which is a better solution to water remediation treatments [36]. If the photocatalytic processes do not take place, the recombination of the $\left(\mathrm{e}^{-}+\mathrm{h}^{+}\right)$pairs happens, and heat is generated in the materials. The photocatalytic activity depends on various factors, including the structure and the dimension of the particles, degree of crystallinity, specific surface area, adsorbed water molecules, and hydroxyl groups [38-41].

The degradation efficiency was further studied in the presence of h- $\mathrm{MoO}_{3}, \mathrm{SiO}_{2}$, and $\mathrm{MoO}_{3} @ \mathrm{SiO}_{2}$ nanoparticle composite in MB dye, and the results are presented in Figure 5. The degradation efficiency was calculated using the following equation [42,43]:

$$
\text { Degradation efficiency }=\left(C_{0}-C\right) / C_{0}(\%)
$$

where $C_{0}$ is the initial dye concentration in the solution, and $C$ is the dye concentration in the solution after irradiation, for a given time interval [42].

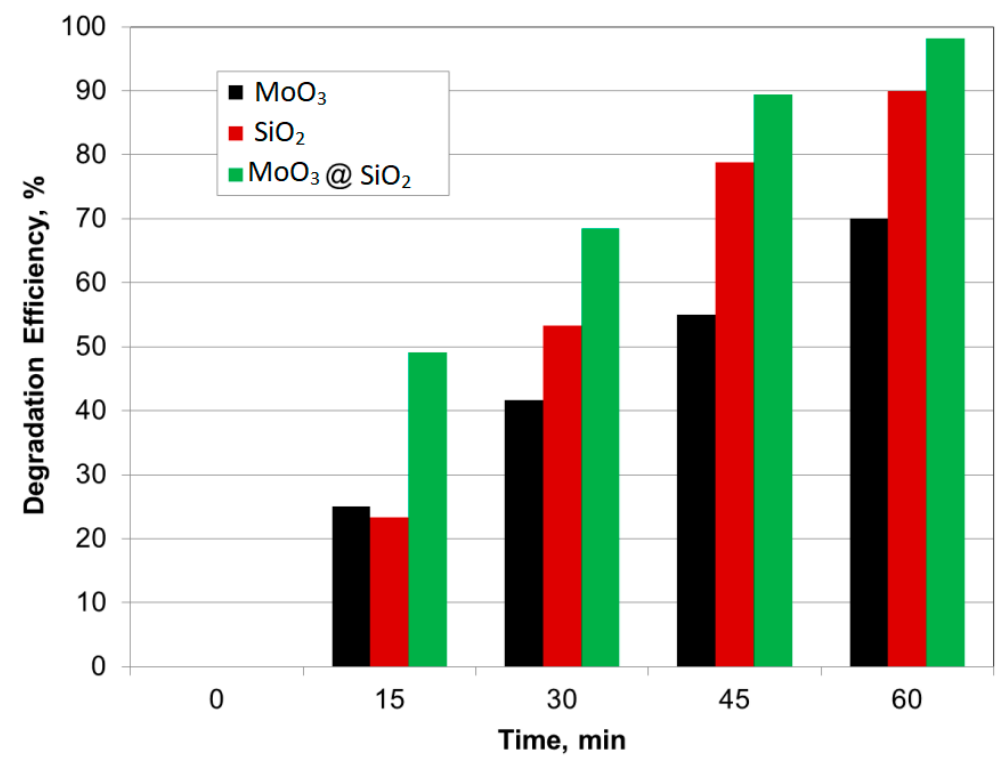

Figure 5. Comparative bar diagram of degradation efficiency for $\mathrm{MoO}_{3}, \mathrm{SiO}_{2}$, and $\mathrm{MoO}_{3} @ \mathrm{SiO}_{2}$. 
Figure 5 shows that the degradation efficiency increases with exposure time under UV-light. The $\mathrm{MoO}_{3} @ \mathrm{SiO}_{2}$ composite showed degradation efficiencies in the $\mathrm{MB}$ solution close to $100 \%$ after 60 min of UV irradiation. The $\mathrm{MoO}_{3} @ \mathrm{SiO}_{2}$ composite showed stable rates of $\mathrm{MB}$ photodegradation up to six cycles.

The rate kinetics analysis, an important parameter in the degradation studies, was performed to predict the rate at which $\mathrm{MB}$ is removed from the aqueous solution [42]. In these experiments, different amounts of $\mathrm{MoO}_{3}, \mathrm{SiO}_{2}$, and $\mathrm{MoO}_{3} @ \mathrm{SiO}_{2}$ composite were used with a fixed concentration of MB. The reaction kinetics was calculated with Equation (8) [42]:

$$
\operatorname{Ln}\left(C / C_{0}\right)=-k t
$$

where $C_{0}$ and $C$ were defined for Equation (7). The graph of the natural logarithm, $\operatorname{Ln}\left(C / C_{0}\right)$ for MB dye versus time in the presence of $\mathrm{MoO}_{3}, \mathrm{SiO}_{2}$, and $\mathrm{MoO}_{3} @ \mathrm{SiO}_{2}$ nanocomposite is presented in Figure 6.

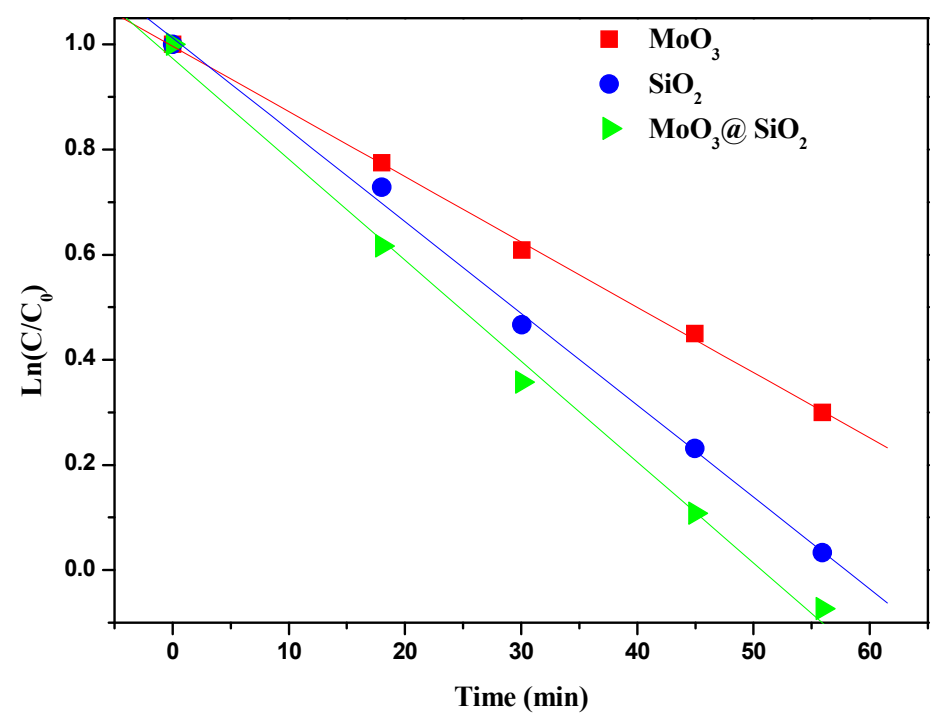

Figure 6. The plots of $\operatorname{Ln}\left(\mathrm{C} / \mathrm{C}_{0}\right)$ versus time for $\mathrm{MoO}_{3}, \mathrm{SiO}_{2}$, and $\mathrm{MoO}_{3} @ \mathrm{SiO}_{2}$.

The MB concentration presented in log scale in Figure 6 varies practically linearly with time, indicating that the photodegradation of MB dye follows the first-order kinetics [42]. The kinetic rate constants $(k)$ were determined from the slope of fitted curves. The first-order degradation rate constants for $\mathrm{MoO}_{3}, \mathrm{SiO}_{2}$, and $\mathrm{MoO}_{3} @ \mathrm{SiO}_{2}$ nanocomposite were $10.3 \times 10^{-3} \mathrm{~min}^{-1}, 15.1 \times 10^{-3} \mathrm{~min}^{-1}$, and $16.3 \times 10^{-3} \mathrm{~min}^{-1}$, respectively. Table 1 presents the rate constants for $\mathrm{MB}$ degradation obtained in this work in comparison to other literature data. The degradation rate of $\mathrm{MB}$ is faster for $\mathrm{MoO}_{3} @ \mathrm{SiO}_{2}$ nanocomposite compared to $\mathrm{MoO}_{3}$ or $\mathrm{SiO}_{2}$.

Table 1. Comparative rate constants for different photocatalysts, including our work.

\begin{tabular}{ccc}
\hline Material & Rate Constants $\times \mathbf{1 0}^{\mathbf{- 3}} \mathbf{~ m i n}^{\mathbf{- 1}}$ & References \\
\hline $\mathrm{MoO}_{3}(\mathrm{CBD})$ & 10.3 & this work \\
$\mathrm{SiO}_{2}$ & 15.1 & this work \\
$\mathrm{MoO}_{3} @ \mathrm{SiO}_{2}$ & 16.3 & this work \\
$\mathrm{MoO}_{3}$ & 0.334 & {$[44]$} \\
$\mathrm{ZnO}$ & 15.15 & {$[6]$} \\
$\alpha-\mathrm{Fe}_{2} \mathrm{O}_{3}$ & 2.01 & {$[45]$} \\
$\mathrm{SnS}_{2}$ & 4.43 & {$[45]$} \\
$\mathrm{SrFe}_{12} \mathrm{O}_{19}$ & 13.6 & {$[46]$} \\
$\mathrm{TiO}_{2}$ & 35.58 & {$[47]$} \\
\hline
\end{tabular}




\section{Conclusions}

We have synthesized $\mathrm{MoO}_{3} @ \mathrm{SiO}_{2}$ nanoparticle composite using chemical bath deposition. The diffraction patterns are in good agreement with the hexagonal phase $\mathrm{MoO}_{3}$ with the lattice parameters of $\mathrm{a}=10.53 \AA$ and $\mathrm{c}=14.876 \AA$. The $\mathrm{SiO}_{2}$ has the following lattice parameters: $\mathrm{a}=25.93 \AA$, $\mathrm{b}=5.01 \AA$, and $\mathrm{c}=18.54 \AA$. The XRD analysis showed that $\mathrm{MoO}_{3}$, silica, and $\mathrm{MoO}_{3} @ \mathrm{SiO}_{2}$ nanoparticle composite have crystalline characteristics phase with an average crystallite size of about $94 \mathrm{~nm}$, $32 \mathrm{~nm}$, and $125 \mathrm{~nm}$, respectively. $\mathrm{SiO}_{2}$ showed micro-flakes morphology with agglomeration as confirmed by SEM analysis, irregular rod-shaped for $\mathrm{MoO}_{3}$, and coral-like structure for $\mathrm{MoO}_{3} @ \mathrm{SiO}_{2}$. The optimum photocatalytic activity was found for $\mathrm{MoO}_{3} @ \mathrm{SiO}_{2}$ nanoparticles, with an efficiency of about $100 \%$ after 60 min of exposure to the UV-light, while the degradation efficiency for the same UV exposure time was about $90 \%$ and $70 \%$ for $\mathrm{SiO}_{2}$ and $\mathrm{MoO}_{3}$, respectively. The degradation rate constants for $\mathrm{MoO}_{3}, \mathrm{SiO}_{2}$, and $\mathrm{MoO}_{3} @ \mathrm{SiO}_{2}$ nanocomposite were $10.3 \times 10^{-3} \mathrm{~min}^{-1}, 15.1 \times 10^{-3} \mathrm{~min}^{-1}$, and $16.3 \times 10^{-3} \mathrm{~min}^{-1}$, respectively. These results show that $\mathrm{SiO}_{2}$ particles have a beneficial photocatalytic effect combined with $\mathrm{MoO}_{3}$ in the $\mathrm{MoO}_{3} @ \mathrm{SiO}_{2}$ composite in the photocatalytic processes.

Author Contributions: Conceptualization: O.K. and A.G.; methodology, O.K. and A.G.; validation, O.K. and A.G.; formal analysis, O.K., B.A., and A.G.; investigation: S.K. and B.A.; resources: A.G. and N.T.-K.; writing-original draft preparation, O.K. and A.G.; writing-review and editing, O.K., A.G., B.A., and R.V.; visualization, O.K., B.A., and A.G.; supervision, N.T.-K. and R.V.; project administration, A.G. and O.K.; funding acquisition, A.G. and N.T.-K. All authors have read and agreed to the published version of the manuscript.

Funding: This research was funded by the Deanship of Scientific Research- Research Center at King Khalid University in Saudi Arabia, code number: GRP-95-41. This project is carried out under the mobility (MOBI) for doctoral and post-doctoral students (DOC) (MOBIDOC) scheme, funded by the European Union (EU) through the Education, Mobility, Research and Innovation (EMORI) program and managed by the National Agency for the Promotion of Scientific Research (ANPR).

Conflicts of Interest: The authors declare no conflict of interest.

\section{References}

1. Bolisetty, S.; Peydayesh, M.; Mezzenga, R. Sustainable technologies for water purification from heavy metals: Review and analysis. Chem. Soc. Rev. 2019, 48, 463-487. [CrossRef]

2. DeCoste, J.B.; Peterson, G.W. Metal-organic frameworks for air purification of toxic chemicals. Chem. Rev. 2014, 114, 5695-5727. [CrossRef]

3. Pichat, P.; Disdier, J.; Hoang-Van, C.; Mas, D.; Goutailler, G.; Gaysse, C. Purification/deodorization of indoor air and gaseous effluents by $\mathrm{TiO}_{2}$ photocatalysis. Catal. Today 2000, 63, 363-369. [CrossRef]

4. Shen, G.; Pan, L.; Zhang, R.; Sun, S.; Hou, F.; Zhang, X.; Zou, J.-J. Low-spin-state hematite with superior adsorption of anionic contaminations for water purification. Adv. Mater. 2020, 32, 1905988. [CrossRef]

5. Zhao, J.; Yang, X. Photocatalytic oxidation for indoor air purification: A literature review. Build. Environ. 2003, 38, 645-654. [CrossRef]

6. Bhatia, S.; Verma, N. Photocatalytic activity of zno nanoparticles with optimization of defects. Mater. Res. Bull. 2017, 95, 468-476. [CrossRef]

7. Li, H.; Wang, P.; Yi, X.; Yu, H. Edge-selectively amidated graphene for boosting $\mathrm{h}_{2}$-evolution activity of $\mathrm{TiO}_{2}$ photocatalyst. Appl. Catal. B Environ. 2020, 264, 118504. [CrossRef]

8. Nandiyanto, A.B.D.; Zaen, R.; Oktiani, R. Correlation between crystallite size and photocatalytic performance of micrometer-sized monoclinic $\mathrm{WO}_{3}$ particles. Arab. J. Chem. 2020, 13, 1283-1296. [CrossRef]

9. Peña-Bahamonde, J.; Wu, C.; Fanourakis, S.K.; Louie, S.M.; Bao, J.; Rodrigues, D.F. Oxidation state of Mo affects dissolution and visible-light photocatalytic activity of $\mathrm{MoO}_{3}$ nanostructures. J. Catal. 2020, 381, 508-519. [CrossRef]

10. Mimouni, R.; Souissi, A.; Madouri, A.; Boubaker, K.; Amlouk, M. High photocatalytic efficiency and stability of chromium-indium codoped $\mathrm{ZnO}$ thin films under sunlight irradiation for water purification development purposes. Curr. Appl. Phys. 2017, 17, 1058-1065. [CrossRef] 
11. Ponce-Mosso, M.; Pérez-González, M.; García-Tinoco, P.E.; Crotte-Ledesma, H.; Morales-Luna, M.; Tomás, S.A. Enhanced photocatalytic activity of amorphous $\mathrm{MoO}_{3}$ thin films deposited by rf reactive magnetron sputtering. Catal. Today 2020, 349, 150-158. [CrossRef]

12. Das, G.S.; Shim, J.P.; Bhatnagar, A.; Tripathi, K.M.; Kim, T. Biomass-derived carbon quantum dots for visible-light-induced photocatalysis and label-free detection of Fe(iii) and ascorbic acid. Sci. Rep. 2019, 9, 15084. [CrossRef]

13. Anghel, D.; Lascu, A.; Epuran, C.; Fratilescu, I.; Ianasi, C.; Birdeanu, M.; Fagadar-Cosma, E. Hybrid materials based on silica matrices impregnated with pt-porphyrin or ptnps destined for $\mathrm{CO}_{2}$ gas detection or for wastewaters color removal. Int. J. Mol. Sci. 2020, 21, 4262. [CrossRef]

14. Wan, J.M.; Wu, Z.Z.; Wang, H.G.; Zheng, X.M. Visible-light photocatalytic degradation of methylene blue with porphyrin-sensitized $\mathrm{TiO}_{2}$. Adv. Mater. Res. 2012, 441, 544-548. [CrossRef]

15. Gholamrezapor, E.; Eslami, A. Sensitization of magnetic $\mathrm{TiO}_{2}$ with copper(ii) tetrahydroxylphenyl porphyrin for photodegradation of methylene blue by visible led light. J. Mater. Sci. Mater. Electron. 2019, 30, 4705-4715. [CrossRef]

16. Fernandes, C.I.; Capelli, S.C.; Vaz, P.D.; Nunes, C.D. Highly selective and recyclable $\mathrm{MoO}_{3}$ nanoparticles in epoxidation catalysis. Appl. Catal. A Gen. 2015, 504, 344-350. [CrossRef]

17. Hanmandlu, C.; Chen, C.-Y.; Boopathi, K.M.; Lin, H.-W.; Lai, C.-S.; Chu, C.-W. Bifacial perovskite solar cells featuring semitransparent electrodes. ACS Appl. Mater. Interfaces 2017, 9, 32635-32642. [CrossRef]

18. Schulz, P.; Tiepelt, J.O.; Christians, J.A.; Levine, I.; Edri, E.; Sanehira, E.M.; Hodes, G.; Cahen, D.; Kahn, A. High-work-function molybdenum oxide hole extraction contacts in hybrid organic-inorganic perovskite solar cells. ACS Appl. Mater. Interfaces 2016, 8, 31491-31499. [CrossRef]

19. Manivel, A.; Lee, G.-J.; Chen, C.-Y.; Chen, J.-H.; Ma, S.-H.; Horng, T.-L.; Wu, J.J. Synthesis of $\mathrm{MoO}_{3}$ nanoparticles for azo dye degradation by catalytic ozonation. Mater. Res. Bull. 2015, 62, 184-191. [CrossRef]

20. Lee, Y.J.; Nichols, W.T.; Kim, D.-G.; Kim, Y.D. Chemical vapour transport synthesis and optical characterization of $\mathrm{MoO}_{3}$ thin films. J. Phys. D Appl. Phys. 2009, 42, 115419. [CrossRef]

21. Liu, F.; Shao, S.; Guo, X.; Zhao, Y.; Xie, Z. Efficient polymer photovoltaic cells using solution-processed $\mathrm{MoO}_{3}$ as anode buffer layer. Sol. Energy Mater. Sol. Cells 2010, 94, 842-845. [CrossRef]

22. Navas, I.; Vinodkumar, R.; Lethy, K.J.; Detty, A.P.; Ganesan, V.; Sathe, V.; Mahadevan Pillai, V.P. Growth and characterization of molybdenum oxide nanorods by rf magnetron sputtering and subsequent annealing. J. Phys. D Appl. Phys. 2009, 42, 175305. [CrossRef]

23. Kamoun, O.; Boukhachem, A.; Alleg, S.; Jeyadevan, B.; Amlouk, M. Physical study of nano-structured $\mathrm{MoO}_{3}$ films codoped with cobalt and nickel in which there is a ferro-diamagnetic transition. J. Alloys Compd. 2018, 741, 847-854. [CrossRef]

24. Kamoun, O.; Boukhachem, A.; Amlouk, M.; Ammar, S. Physical study of Eu doped $\mathrm{MoO}_{3}$ thin films. J. Alloys Compd. 2016, 687, 595-603. [CrossRef]

25. Kamoun, O.; Mami, A.; Amara, M.A.; Vidu, R.; Amlouk, M. Nanostructured Fe,Co-codoped $\mathrm{MoO}_{3}$ thin films. Micromachines 2019, 10, 138. [CrossRef]

26. Desai, N.; Mali, S. Chemically grown $\mathrm{MoO}_{3}$ nanorods for antibacterial activity study. J. Nanomed. Nanotechnol. 2015, 6, 338. [CrossRef]

27. Dhara, A.; Hodes, G.; Sarkar, S.K. Two stage chemical bath deposition of $\mathrm{MoO}_{3}$ nanorod films. RSC Adv. 2014, 4, 53694-53700. [CrossRef]

28. Konnert, J.H.; Appleman, D.E. The crystal structure of low tridymite. Acta Crystallogr. 1978, B34, 13. [CrossRef]

29. Tridymite, R. Available online: https://rruff-2.Geo.Arizona.Edu/tridymite/r090042 (accessed on 10 February 2020).

30. Edy, R.; Huang, G.; Zhao, Y.; Guo, Y.; Zhang, J.; Mei, Y.; Shi, J. Influence of reactive surface groups on the deposition of oxides thin film by atomic layer deposition. Surf. Coat. Technol. 2017, 329, 149-154. [CrossRef]

31. Kamoun, O.; Boukhachem, A.; Mrabet, C.; Yumak, A.; Petkova, P.; Boubaker, K.; Amlouk, M. Effect of europium content on physical properties of $\operatorname{In}_{2} \mathrm{O}_{3}$ thin films for sensitivity and optoelectronic applications. Bull. Mater. Sci. 2016, 39, 777-788. [CrossRef]

32. Li, X.-L.; Liu, J.-F.; Li, Y.-D. Low-temperature synthesis of large-scale single-crystal molybdenum trioxide $\left(\mathrm{MoO}_{3}\right)$ nanobelts. Appl. Phys. Lett. 2002, 81, 4832-4834. [CrossRef]

33. Senthilkumar, R.; Anandhababu, G.; Mahalingam, T.; Ravi, G. Photoelectrochemical study of $\mathrm{MoO}_{3}$ assorted morphology films formed by thermal evaporation. J. Energy Chem. 2016, 25, 798-804. [CrossRef] 
34. Ramana, C.V.; Atuchin, V.V.; Troitskaia, I.B.; Gromilov, S.A.; Kostrovsky, V.G.; Saupe, G.B. Low-temperature synthesis of morphology controlled metastable hexagonal molybdenum trioxide $\left(\mathrm{MoO}_{3}\right)$. Solid State Commun . 2009, 149, 6-9. [CrossRef]

35. Joni, I.M.; Nulhakim, L.; Vanitha, M.; Panatarani, C. Characteristics of crystalline silica $\left(\mathrm{SiO}_{2}\right)$ particles prepared by simple solution method using sodium silicate $\left(\mathrm{Na}_{2} \mathrm{SiO}_{3}\right)$ precursor. J. Phys. Conf. Ser. 2018, 1080, 012006. [CrossRef]

36. Wongkrua, P.; Thongtem, T.; Thongtem, S. Synthesis of h- and $\alpha-\mathrm{MoO}_{3}$ by refluxing and calcination combination: Phase and morphology transformation, photocatalysis, and photosensitization. J. Nanomater. 2013, 2013, 702679. [CrossRef]

37. Mimouni, R.; Askri, B.; Larbi, T.; Amlouk, M.; Meftah, A. Photocatalytic degradation and photo-generated hydrophilicity of methylene blue over $\mathrm{ZnO} / \mathrm{ZnCr}_{2} \mathrm{O}_{4}$ nanocomposite under stimulated UV light irradiation. Inorg. Chem. Commun. 2020, 115, 107889. [CrossRef]

38. Chen, Y.; Lu, C.; Xu, L.; Ma, Y.; Hou, W.; Zhu, J.-J. Single-crystalline orthorhombic molybdenum oxide nanobelts: Synthesis and photocatalytic properties. CrystEngComm 2010, 12, 3740-3747. [CrossRef]

39. Ku, Y.; Huang, Y.-H.; Chou, Y.-C. Preparation and characterization of $\mathrm{ZnO} / \mathrm{TiO}_{2}$ for the photocatalytic reduction of $\mathrm{Cr}(\mathrm{vi})$ in aqueous solution. J. Mol. Catal. A Chem. 2011, 342-343, 18-22. [CrossRef]

40. Song, L.X.; Xia, J.; Dang, Z.; Yang, J.; Wang, L.B.; Chen, J. Formation, structure and physical properties of a series of $\alpha-\mathrm{MoO}_{3}$ nanocrystals: From 3d to $1 \mathrm{~d}$ and 2d. CrystEngComm 2012, 14, 2675-2682. [CrossRef]

41. Vijay, M.; Selvarajan, V.; Sreekumar, K.P.; Yu, J.; Liu, S.; Ananthapadmanabhan, P.V. Characterization and visible light photocatalytic properties of nanocrystalline $\mathrm{TiO}_{2}$ synthesized by reactive plasma processing. Sol. Energy Mater. Sol. Cells 2009, 93, 1540-1549. [CrossRef]

42. Mageshwari, K.; Mali, S.S.; Sathyamoorthy, R.; Patil, P.S. Template-free synthesis of mgo nanoparticles for effective photocatalytic applications. Powder Technol. 2013, 249, 456-462. [CrossRef]

43. Tariq, N.; Fatima, R.; Zulfiqar, S.; Rahman, A.; Warsi, M.F.; Shakir, I. Synthesis and characterization of $\mathrm{MoO}_{3} / \mathrm{CoFe}_{2} \mathrm{O}_{4}$ nanocomposite for photocatalytic applications. Ceram. Int. 2020, 46, 21596-21603. [CrossRef]

44. Anjaneyulu, R.B.; Mohan, B.S.; Naidu, G.P.; Muralikrishna, R. Visible light enhanced photocatalytic degradation of methylene blue by ternary nanocomposite, $\mathrm{MoO}_{3} / \mathrm{Fe}_{2} \mathrm{O}_{3} / \mathrm{rGO}$. J. Asian Ceram. Soc. 2018, 6, 183-195. [CrossRef]

45. Balu, S.; Uma, K.; Pan, G.-T.; Yang, T.C.-K.; Ramaraj, S.K. Degradation of methylene blue dye in the presence of visible light using $\mathrm{SiO}_{2} @ \alpha-\mathrm{Fe}_{2} \mathrm{O}_{3}$ nanocomposites deposited on $\mathrm{SnS}_{2}$ flowers. Materials 2018, 11, 1030. [CrossRef]

46. Mishra, D.D.; Tan, G. Visible photocatalytic degradation of methylene blue on magnetic $\mathrm{SrFe}_{12} \mathrm{O}_{19}$. J. Phys. Chem. Solids 2018, 123, 157-161. [CrossRef]

47. Xu, Y.-H.; Liang, D.-H.; Liu, M.-L.; Liu, D.-Z. Preparation and characterization of $\mathrm{Cu}_{2} \mathrm{O}-\mathrm{TiO}_{2}$ : Efficient photocatalytic degradation of methylene blue. Mater. Res. Bull. 2008, 43, 3474-3482. [CrossRef]

Publisher's Note: MDPI stays neutral with regard to jurisdictional claims in published maps and institutional affiliations.

(C) 2020 by the authors. Licensee MDPI, Basel, Switzerland. This article is an open access article distributed under the terms and conditions of the Creative Commons Attribution (CC BY) license (http://creativecommons.org/licenses/by/4.0/). 